\title{
The Effectiveness of the Quality Management System of Small and Medium-sized Enterprises
}

\author{
Budiono $^{1}$, Sujoko ${ }^{2}$, Sugiyono ${ }^{3}$ \\ ${ }^{1,2}$ University of Technology Yogyakarta \\ ${ }^{3}$ State University of Yogyakarta \\ buditulada@gmail.com, ${ }^{1}$ sujokod2.01@gmail.com, ${ }^{2}$ sugiyono_1953@yahoo.com
}

\begin{abstract}
The process of SME's decision making as a company related in how far the SMEs put the foundation of motivational process. The research aims to explore "Why" concept [1] within the core decision making process of SMEs in competing with the global business. "Why" concept related with 'How', 'What' and 'When' a decision can be made. This particular idea became important with the goal of how SMEs especially within Indonesia wouldn't stuck in dead ends in making growth and accelerating SME's organization development which consistently crushed and overwhelmed by global business. From the interconnection between variables, formed a chart which represents complete concept within a quality decision making process in manifesting effective SMES. The research conducted by having 81 SMEs respondents which resides in Indonesia, specifically Special Region of Yogyakarta. The result of the research is, discovery of a SME's quality decision making (QDM) process chart for SME's effectiveness. The implication of the research is that the effective SMEs organizations required to conduct assessments and implementations of "Why" concept as a motivation towards 'How', 'What' and 'When' a QDM exercised for SME's effectiveness.
\end{abstract}

Keywords: SMES, decision making, WHY concept, SMES's effectiveness

\section{Introduction}

SMES possess vital role for ASEAN economy up until now, $96 \%$ of ASEAN corporations are SMES.50\% of SMEs contributed from $30 \%$ until $50 \%$ in gross domestic product (GDP); another fact is that $19 \%$ until $31 \%$ SMEs contributed towards exports [2].

Business environment keeps changing, its challenges and expectations keep increasing, that as an organization of business especially the manager should be prepare for the upcoming circumstances [3]. Furthermore, microfinance service institutions with low overall assets. Organization effectiveness (OE) very much has to do with its effectiveness done by a manager. Managerial effectiveness towards employees or staffs depends on how a manager provide motivation to its subordinate. A manager can't be arbitrary, forceful and rude attitudes can't sustain long term effectiveness of managerial [4], in this matter, OE fundamentally determined by manager's role within organization or company.

Manager became an ultimate key of how a company could run effectively. Flexibility enable the decision making increase by allowing the most relevant approach selection with certain social and organizational context. Decision making learning can be conducted with many ways, within individual or group, and able to cover experiences within a course or organizational program or academically [5]. Behaviors and habits which derived from social status could bring impact in how the institution will attain its level of effectiveness. This matter can become a guide in how ineffective institutions adjust its treatment and behavior within.

Manager's leadership effectiveness within the organization influence towards many issues, for instance, employee's satisfaction towards the manager's leadership, from this point institutions effectiveness built through cohesive cooperation of the members. Human resources are the key element in enriching an organizational assets, since its own sustainable competitive advantage and increasing efficiency of employees [6].

Technological leadership, communication and technological facilities, managers commitments are also linked towards institution managerial tasks [7]. The very existence of technology with its component and dimension has strong influence towards becoming effective institutional managerial. This approach aim to obtain more accurate prediction in order to prepare against every disruption so the institution can keep maintaining its effectiveness.

OE can be seen from the prominent achievement of the organization or institution [8]. If an institution achieves decent short or long term targets, then such institution considered as effective one. In the other hand, if an institution possess even latest and potent tools available but failed to achieve targets, then such institution considered the otherwise. Such measurement done with the hope that it can be really implemented within managerial conducts of institution as optimal as possible, this can be used as guidance and evaluation material for the future so that the institution keeps improving.

Effectiveness is the result of organizational processes or certain ability level to achieve objectives. Related with this matter, Sangsurin et. al didn't describe how decision making taken by academic manager specifically. Therefore, the research will discuss of how an academic manager obtain its capacity as a decision maker. The better quality of decision making process by the manager, the closer it achieves the institution's effectiveness. 
Every managers undoubtedly concern 4 business cycles; climax (prosperity), recession (degradation), trench (worst depression) and recovery cycle (expansion). Through these cycles, managers are able to describe business classification types [9]. Therefore, the managers concern about how the decision making will be conducted in the future.

Positivists argued that good decision making attainable if organization issues dimension explained accurately. Therefore, identification of factors which contributes towards OE issue can be explained [10]. The existence of manager's role tends to improve organization effectiveness. A manager needs to have several raw capacities in order to achieve strong managerial which helps the realization of effective institution. Managerial of manager integrated within its attitudes and actions in how they conduct decision making, "Does one has certain level of emotional intelligence so that one able to deliver well - mannered self impression and effective communication in one's effort to achieves effective institution.

Corporate decision making often made by effective logical decision making foundation. The manager as a decision maker utilize available tools in order to do so. The manager focused on the selection of the desired outcome which might occurs. The manager took certain effect and focus on the selection of method in creating the particular effect. Effective logic considering the control of the logic and not the prediction of the logic. The manager start with a new available method with favorable risk level. Evaluation expected to repair the planning in order to obtain maximum result of the efforts and investments. Through particular way of reasoning, one able to understand how relatively weak human - resources SMES has the capacity to develop kinds of opportunities.

Role - playing logic is important in developing SMEs. Orientation which pledged should be able to motivate the development of SMEs opportunities [11]. Selected strategic decision approach is not bound by the size of the corporation, instead it's bound with the decision's context. The corporation shows the ability to switch between effective and causal decision model according to the decision which based on condition context [12]. SME's manager has to develop framework and identify the main enriching factors of one's intelligence in order to make effective decision [13].

A decision making quality model towards OE draft ever suggested by Negulescu \& Doval [14]. Furthermore, the draft needs to be examined thoroughly especially within the motivational issue. Such motivational issue didn't get a comprehensive explanation. Through consideration and comparison of factors as mentioned above [11]- [13] along with a concept of motivational factor which mentioned as "Why" concept [1], therefore the draft is complete. The predominance of such completion is simpler and easier to understand due to its enabling visualization on how components are related in making QDM.

\section{Literature Survey}

\subsection{SMEs}

Actions, processes, and activities, whereas creativity, risk taking, and innovation play important role within SMEs. The substance of entrepreneurship behavior can occurs between existing entrepreneur and firm, including those who established for a long period of time, and the innovation systemization, and commercialization with existing firm [15]. The main part of SMEs effectiveness dynamic as a firm is how supporting component of decision making deliver quality outcomes. Through such quality process SMEs development will definitely accelerated in achieving its goals.

\subsection{Decision making}

Every manager required strong tenacity and high thoroughness in receiving information and calculating the taken risk. Decision making's role within this matter is urgently needed. Every organization required decision making, including SMEs institutions. Every decision contains cognitive and emotion [16].

Creating decision is among the main duties of the organization itself, including employees and other stake holders [14]. In doing so, a manager has the biggest contribution to make that happen. Sufficient provision and reliable skills should be owned by a manager in order to deliver maximum outcome. A manager also ought to have reliability in ensuring the organization/institution run effectively and sustainably.

Decision making is behavior or mental commitment for certain action. Decision making shows informational process activity from single decision maker, or double decision maker. Decision making always started with problem identification, treatment alternative, until the decision to choose. To be implemented and evaluated. decision making is deliberate activity to choose two or more option proactively, during uncertainty situation, in order to achieve goals, targets, or certain result with the minimum risk [17].

Decision making for the majority of the manager is considered as the main duty, since the manager required to continuously decide what to be done, who's perform it, when, where and how it should be done. Perhaps one may argued that a manager faces a situation (opportunity or threat) which required decision making in all activities. Therefore, decision making is vital in all managerial and organizational activities [17]

It's meant to be that the decision making should be conducted by every manager through well - consideration, procedural, and quality - oriented. It's obvious that the manager as the leader didn't make the decision "blind folded" yet how the decision that made are the best and effective for the organization.

The quality of decision making much more urgent compared to the quantity of it. It's considered useless when one has made decision through all procedures and phases but turns out with no quality. The numbers of no quality DM within 
the organization will create another problem. Therefore, the quality of the decision making is considered as urgent matter [18]. QDM will give significant positive influence towards institution's effectiveness [14].

The process of QDM is achievable through the calculation of several strong support factor, such as environment, organization strategy, ethics, empowerment, information, feedback, program, option, risk avoidance, resources and opportunity [14]. The power of QDM is influenced by information which get into the organization and its manager [19]. The information is the knowledge which has to be managed a certain way by the manager since it has dominant effect towards, however the manager which focused on effectiveness will not be hasty to utilize its power excessively beyond its boundary. The quality of decision making is the process which requires consideration of the main support within the conceptual model of QDM for OE [14].

With QDM, the manager will deliver effectiveness of the institution. The basic which necessary to make decision making into qualified one is important and urgent. To secure public trust and increase safety rule ratio, it's necessary to develop decision making framework based on risks information [20].

QDM has accuracy definition and truth of institution in making proper decision with the institution's capability [21]. Decision became hard when there are values to be considered in the same time along with the sacrifice which should be made by itself or when there are possibilities of the future which should be considered at the same time, and those uncertainty needs to be calculated. Tools are available for issues arrangement and evaluation which discuss both types of difficulties [22].

\subsection{Organization Effectiveness (OE)}

Effectiveness is organizational capability to overcome the lack of confidence which appeared from the nearby environment and organization which create its environment towards desired outcome. Multi - criteria approach, effective ideas are based on how organization achieve its goal, fulfilling certain requirements and keeping necessary standard.

John Gardner [23] argued that effective organization has rules, first, has effective program for recruitment and talents development; second, has sustainable innovation in which the organization should be individual - friendly; third, has set of provisions to self - correct; fourth, has a fluidity within its internal structure; fifth, has a method to combine processes in which by that people become attached by their procedures.

Effective organization [23] has characteristic features, such as managing jobs or activities to achieve goals and targets completely. Issues, tasks, or projects determine how human resources managed. Decision made with correct information. Tight reward system for production, growth and development performances. Lateral and vertical communication run smoothly. Conflict between individual and group is relatively little. Every conflict resolution didn't deplete much energy.

Organization manager is the driver of organization. Organization manager direct the institution, and not take its position for granted, such as taking it for personal or limited advantage. Similar to aboard a ship, a manager can be seen as skipper, utilizing wind direction even facing storm to get to the desired direction. After getting the right track, all ship crew know where to go, this then use to mark more specific progress [24].

\section{4 "Why" concept}

"Why" concept [1] is not an attitude or perspective of a motivation to be always become better than the others. The challenge is not out performed others, instead the spirit and believe that tomorrow is better than today. Everyone can convince themselves and their teams that they can change into better one. Everyone in the team understood that the service they gave towards customers always increasing and getting better from previous. This concept can change one's world view, that one is tough to be defeated. The spirit once again is not about defeating others, but how to conquer oneself, a self which doesn't feel superior towards others. This particular concept which then make an organization hard to be defeated by others. Previous research has helped to identify 16 factors that shapes the information gathering and usage of SMEs manager behavior during new technology - adopted decision making [13]. The essence of the research findings is the part of "Why" concept which emphasizes on details from how a manager gather accurate information through various angles.

"Why" concept emphasizes that a leader with such concept should embrace a method of how to inspire and not manipulate staffs and employees to take action. Therefore, the action which taken by the employees merely based on their awareness, intention, and consent to do the best for the company, this the key why a company is hard to be defeated. The strong will which fully internalize within a member of the company is the one which makes the company obtain source of power which will exceeds the boundaries that often illustrated by people as limitation. From there, every corner of the company has the increasing quality. The company felt free from other competitors. This in fact which will uphold the company position into the front. The manager don't always think that everything is about money. But more on how the customer receives ease of accessibility and fulfilled its needs and goals. That explanation embedded in the figure below. "Why" concept become source of ideas and the foundation in creating QDM.

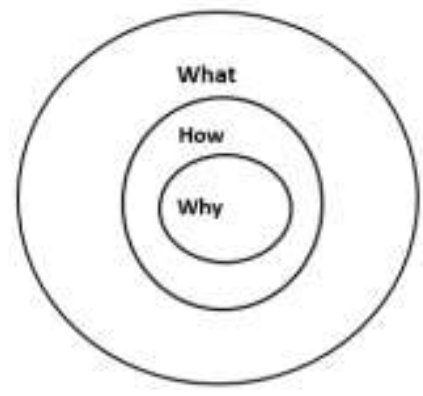

Figure 1: Why Concept in Golden Circle (Sinek, 2009) 


\section{Methodology}

This research explores all employees regardless their position in their SMEs circumstances, therefore, a clear and complete picture in how a decision made in SMEs can be delivered. This method was taken with the assumption that every employees have their position independently. In doing so, such method will increase the awareness especially in SMEs that every employees deserve a right to speak their concern which aimed to increase the sense of belonging towards the institution or the company. This research using qualitative - analyses method towards manager behavior in decision making based on likert - type questionnaire [25].

The details of questionnaire distribution is 81 people, consist of 26 females and 55 males. With the composition of 44 people (general manager and division) and 37 people of common manager. Indicators establishment of the questionnaire developed as how previous research were conducted [14] with some adaptation along with 11 indicators from new development called support factor.

Table 1: Respondents profile

\begin{tabular}{|c|c|c|}
\hline Gender & $32 \%$ female & $68 \%$ male \\
\hline Position in the SME & $45 \%$ leader & $55 \%$ sub - manager \\
\hline Involvement & $83 \%<10$ years & $17 \%>10$ years \\
\hline
\end{tabular}

Qualitative questions that used by the research shown below:

1) How the decision making process conducted by the leader of your institution?

2) What type of decision making that done by the leader?

3) When a manager make a decision making?

4) Why a decision that made by the institution took place on certain time and shape, how is the process?

Through these 4 questions which elaborated through detail of the question later analyzed and combined within a chart as a figure which will ease the managers to understand the process of how QDM conducted.

\section{Result}

Through analyzing and understanding the questionnaires which distributed to SMEs personnel, findings of the research shown as below:

As mentioned in table 1, company (SMEs) in decision making highly concern towards its environment. Institutional existence become the urgent consideration within decision making process $(42 \%)$. This matter shown intensity of dominant consideration compared other factors. As mentioned by Brown (Murphy \& Longo, 2009) that the existence of conducive environment will increase company focus, so that it can increase the productivity. Internal condition and existential development of the company became the main priority, and this matter indeed a strategic goal of the company, as within the findings (37\%). This strengthen with complete perspective and understanding towards ethics principle which become the company vision $(30 \%)$.
Table 2: How the SMEs conduct decision making

\begin{tabular}{|c|c|c|c|c|c|}
\hline How & $\begin{array}{c}\text { Not } \\
\text { agreed } \\
(\%)\end{array}$ & $\begin{array}{c}\text { Partial } \\
\text { agreed } \\
(\%)\end{array}$ & $\begin{array}{c}\text { Total } \\
\text { agreed } \\
(\%)\end{array}$ & Mean & $\begin{array}{c}\text { Std. } \\
\text { Deviation }\end{array}$ \\
\hline $\begin{array}{c}\text { Concerning } \\
\text { environmental factor }\end{array}$ & 1 & 56 & 43 & 2.4125 & 0.5203 \\
\hline $\begin{array}{l}\text { Looking for current } \\
\text { problem solving } \\
\text { (urgent) }\end{array}$ & 2 & 75 & 23 & 2.2250 & 0.4493 \\
\hline $\begin{array}{c}\text { Focus on problem } \\
\text { solving implementation } \\
\text { and monitoring }\end{array}$ & 3 & 70 & 27 & 2.2500 & 0.4904 \\
\hline $\begin{array}{l}\text { Depends on received } \\
\text { information quality in } \\
\text { the institution }\end{array}$ & 10 & 79 & 11 & 2.0127 & 0.4667 \\
\hline $\begin{array}{c}\text { Based on strategic } \\
\text { objective of institution }\end{array}$ & 3 & 60 & 37 & 2.3500 & 0.5301 \\
\hline $\begin{array}{l}\text { Influenced by running } \\
\text { culture of organization }\end{array}$ & 23 & 69 & 8 & 1.8625 & 0.5453 \\
\hline $\begin{array}{c}\text { Recommended by } \\
\text { member of } \\
\text { managers/leaders team }\end{array}$ & 22 & 76 & 2 & 2.2125 & 0.4413 \\
\hline $\begin{array}{c}\text { Delegation towards } \\
\text { certain team }\end{array}$ & 14 & 75 & 11 & 1.9750 & 0.5025 \\
\hline $\begin{array}{l}\text { Tends to imply } \\
\text { subordinate aspiration } \\
\text { within the institution }\end{array}$ & 13 & 74 & 13 & 2.0125 & 0.5154 \\
\hline $\begin{array}{c}\text { Seeking the } \\
\text { strengthening of } \\
\text { institution existence }\end{array}$ & 1 & 75 & 24 & 2.2250 & 0.4493 \\
\hline $\begin{array}{c}\text { Based on ethical } \\
\text { principle which } \\
\text { becomes the vision of } \\
\text { institution }\end{array}$ & - & 70 & 30 & 2.3000 & 0.4611 \\
\hline $\begin{array}{c}\text { Based on routine which } \\
\text { done before within the } \\
\text { institution }\end{array}$ & 29 & 68 & 3 & 1.7500 & 0.5156 \\
\hline
\end{tabular}

The process of how SMEs made the decision in order to have quality result, related with types or model of the how the decision making conducted. Based on Table 2 below, it shows that options which visualize the shape of how the decision making that taken $(57 \%)$. The majority of respondent stated that the type of an SMEs decision making dominantly influences the shape of the decision. SMEs always choose the option which rational, profitable, and which general analyses recommend or approve the options which considered as quality one $(51 \%)$. SMEs in order to be effective, avoid the decision making which based on incomplete input or information.

Table 3: What is your company's type of decision

\begin{tabular}{|c|c|c|c|c|c|c|c|}
\hline What & $\begin{array}{c}\text { About } \\
\text { none } \\
\%\end{array}$ & $\begin{array}{c}\text { A few } \\
\%\end{array}$ & $\begin{array}{c}\text { About } \\
\text { Half } \\
\%\end{array}$ & $\begin{array}{c}\text { A lot } \\
\%\end{array}$ & $\begin{array}{c}\text { About } \\
\text { all } \\
\%\end{array}$ & Mean & $\begin{array}{c}\text { Std. } \\
\text { Deviation }\end{array}$ \\
\hline $\begin{array}{c}\text { Planned } \\
\text { programing }\end{array}$ & 13 & 35 & 45 & 7 & - & 4.0125 & 0.7712 \\
\hline $\begin{array}{c}\text { Un- } \\
\text { programmed, } \\
\text { unplanned }\end{array}$ & 15 & 50 & 31 & 4 & - & 2.2375 & 0.7504 \\
\hline $\begin{array}{c}\text { Based on } \\
\text { familiar } \\
\text { options }\end{array}$ & 3 & 7 & 18 & 57 & 15 & 3.7625 & 0.8750 \\
\hline $\begin{array}{c}\text { Based on } \\
\text { incomplete } \\
\text { information }\end{array}$ & 25 & 56 & 17 & 2 & - & 1.9500 & 0.6917 \\
\hline Using & 1 & 10 & 26 & 51 & 12 & 3.6625 & 0.8259 \\
\hline
\end{tabular}




\begin{tabular}{|c|c|c|c|c|c|c|c|}
\hline $\begin{array}{c}\text { scientific } \\
\text { method }\end{array}$ & & & & & & & \\
\hline $\begin{array}{c}\text { Based on } \\
\text { skill without } \\
\text { reasoning in } \\
\text { the first } \\
\text { place }\end{array}$ & 27 & 53 & 15 & 5 & - & 1.9500 & 0.7614 \\
\hline $\begin{array}{c}\text { Within risky } \\
\text { situation }\end{array}$ & 13 & 35 & 45 & 7 & - & 2.4750 & 0.8109 \\
\hline
\end{tabular}

Within decision making, SMEs always has the reason to overcome the current issue $(63 \%)$ as shown in table 3 . This align with the capability of SMEs to preserve its existence and productive ability which profitable. Based on the very basic abilities, they able to increase institution's effectiveness. In that particular condition SMEs will be improved in maximum. The perfect moment idolized by every SMEs in deciding quality decision.

Table 4: When is the company made the decision?

\begin{tabular}{|c|c|c|c|c|c|}
\hline When & $\begin{array}{c}\text { Not } \\
\text { agreed } \\
(\%)\end{array}$ & $\begin{array}{c}\text { Partial } \\
\text { agreed } \\
(\%)\end{array}$ & $\begin{array}{c}\text { Total } \\
\text { agreed } \\
(\%)\end{array}$ & Mean & $\begin{array}{c}\text { Std. } \\
\text { Deviation }\end{array}$ \\
\hline Identifying problems & 2 & 74 & 24 & 2.2250 & 0.4691 \\
\hline Knowing problems & 3 & 71 & 26 & 2.2938 & 0.4838 \\
\hline $\begin{array}{c}\text { Having a reason to } \\
\text { solve the problem }\end{array}$ & 1 & 63 & 36 & 2.3188 & 0.5057 \\
\hline $\begin{array}{c}\text { Having the resources } \\
\text { to solve the problem }\end{array}$ & - & 71 & 29 & 2.2688 & 0.4555 \\
\hline $\begin{array}{c}\text { Having the } \\
\text { opportunity to increase } \\
\text { effectiveness }\end{array}$ & - & 75 & 25 & 2.2500 & 0.4357 \\
\hline
\end{tabular}

The reason or strong motivation in every quality decision have solid reliability. As shown in table 4, more and more sincere motivation from the members of the company increasingly strengthening company existence. Between the motivations in the research, it shows that $64 \%$ decision made based on the spirit principle of prospering the society. In the other hand, the spirit to be better than self/institution and not to defeat others, as much as $54 \%$ respondent stated that this factor is the one that influence QDM which keeps the company moving forward to achieve its goal without having to be burdened by surrounding competitors. In doing so, the spirit to self - improvement, to become better than now, becomes flourished. The action also followed by not underestimate other people/institution, a spirit to increase institution quality and its manager [1]

The leaders put effort to inspire people to do the best course for the company. The leaders avoid malingering attitude in behaving towards all of the company member.

Table 5: Why a company conduct a certain decision

\begin{tabular}{|c|c|c|c|c|c|}
\hline Why? & $\begin{array}{c}\text { Not } \\
\text { agreed } \\
(\%)\end{array}$ & $\begin{array}{c}\text { Partial } \\
\text { agreed } \\
(\%)\end{array}$ & $\begin{array}{c}\text { Total } \\
\text { agreed } \\
(\%)\end{array}$ & Mean & $\begin{array}{c}\text { Std. } \\
\text { Deviation }\end{array}$ \\
\hline $\begin{array}{c}\text { Living the belief of } \\
\text { organization's } \\
\text { principle }\end{array}$ & - & 64 & 36 & 2.3625 & 0.4838 \\
\hline $\begin{array}{c}\text { Preserving the spirit } \\
\text { of prospering the } \\
\text { society principle }\end{array}$ & - & 58 & 42 & 2.4250 & 0.4975 \\
\hline $\begin{array}{c}\text { Developing the } \\
\text { existing institutional }\end{array}$ & - & 65 & 35 & 2.3500 & 0.4800 \\
\hline
\end{tabular}

\begin{tabular}{|c|c|c|c|c|c|}
\hline cooperation potential & & & & & \\
\hline \begin{tabular}{|c|} 
The spirit to outplay \\
oneself/self - \\
organization (not to \\
outplay others/other \\
- organization)
\end{tabular} & 1 & 45 & 54 & 2.5250 & 0.5271 \\
\hline $\begin{array}{c}\text { The spirit to improve } \\
\text { oneself, better than } \\
\text { today }\end{array}$ & 1 & 48 & 51 & 2.5000 & 0.5277 \\
\hline \begin{tabular}{|c|} 
Not demeaning \\
others/other - \\
institution, increase \\
institution and its \\
managerial quality
\end{tabular} & - & 51 & 49 & 2.4875 & 0.5030 \\
\hline \begin{tabular}{|c|} 
Increasing the \\
institution's revenue \\
and profit
\end{tabular} & 2 & 64 & 34 & 2.3125 & 0.5179 \\
\hline \begin{tabular}{|c|} 
Developing the \\
institution's revenue \\
and profit
\end{tabular} & 1 & 54 & 45 & 2.4375 & 0.5240 \\
\hline \begin{tabular}{|c|} 
Evaluating \\
institution's \\
accomplishments
\end{tabular} & 1 & 55 & 44 & 2.4250 & 0.5223 \\
\hline $\begin{array}{l}\text { The leaders put } \\
\text { effort to inspire the } \\
\text { people to do their } \\
\text { best within the } \\
\text { company }\end{array}$ & 2 & 64 & 34 & 2.3125 & 0.5179 \\
\hline $\begin{array}{l}\text { The leaders stay } \\
\text { away from } \\
\text { dissemblance in } \\
\text { taking action and } \\
\text { ignoring all people } \\
\text { of the company }\end{array}$ & 1 & 65 & 34 & 2.3250 & 0.4975 \\
\hline
\end{tabular}

From the discussion of QDM in SMEs, it can be formulated a chart as below:

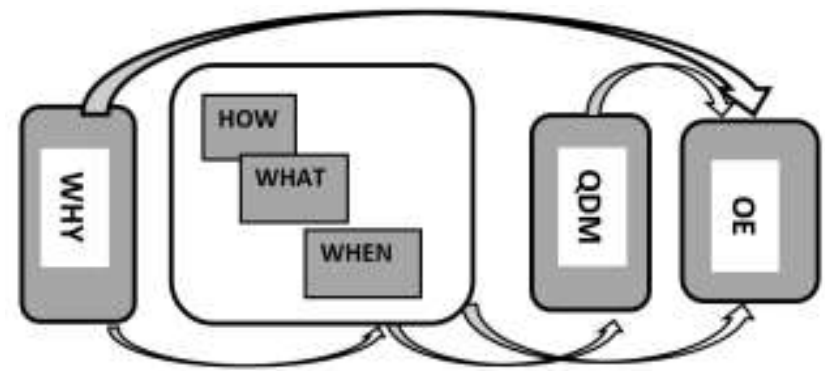

Figure 1: Chart of the Quality Decision Making Process for Organizational Effectiveness

From the chart, it is clear that the main motivational factor is "Why" concept in laying the foundation of quality decision. With this motivation, all variables in QDM becomes guided and understandable through existing variables. This becomes the recommendation for SMEs to be always concern and implementing the content of the chart.

Based on the chart, it is important for decision maker in every structural level of the company or SMEs to make "Why" concept as the foundation of every decision making component. The impact of "Why" concept becomes the real way to create effective organization. 


\section{Conclusion}

"Why' concept is main motivation in how, what and when a QDM conducted. The relations between concepts in the chart is strategic to make effective SMEs as a company. The process of QDM is very linked with "Why", how, what, and when a decision taken. The accuracy of inter - variable very determined the quality of decisions within the company. Such factors considered urgent for a company to be solved. This research limited only in motivational aspect for QDM process.

\section{Future Scope}

Further research is advised to be conducted, to examine more on the influence of inter - variable within the chart, in contributing the effectiveness of company or institution.

\section{References}

[1] S. Sinek, START WITH WHY. New York: Penguin Group, 2009.

[2] "Pengertian UKM \& UMKM? Bagaimana Menjadi Usaha Kecil Menengah di Indonesia, " 2016. [Online]. Available: https: //goukm. id/.

[3] C. Pérez - Cornejo, E. de Quevedo - Puente, and J. B. Delgado - García, "How to manage corporate reputation? The effect of enterprise risk management systems and audit committees on corporate reputation," Eur. Manag. J., vol.37, no.4, pp.505-515, 2019, doi: 10.1016/j. emj.2019.01.005.

[4] R. Sloof and F. A. von Siemens, "Effective leadership and the allocation and exercise of power in organizations, " Leadersh. Q., p.13, 2019, doi: 10.1016/j. leaqua.2018.12.001.

[5] R. Holian, "Management decision making, ethical issues and 'emotional' intelligence," Manag. Decis., vol.44, no.8, pp.1122-1138, 2006, doi: $10.1108 / 00251740610690658$.

[6] M. Pasban and S. H. Nojedeh, "A Review of the Role of Human Capital in the Organization," Procedia - Soc. Behav. Sci., vol.230, no. May, pp.249-253, 2016, doi: 10.1016/j. sbspro.2016.09.032.

[7] A. Raman and S. B. Shariff, "Relationship Between Technology Leadership, ICT Facility, Competency, Commitments Towards Effectiveness of School Mangement Tasks in Schools, "Pedagog. J. Pendidik., vol.7, no.1, p.4, 2018, doi: 10.21070/pedagogia. v7i1.1292.

[8] A. Manoharan and M. Singal, "Organizational effectiveness in hospitality: Managers perspectives, " Int. J. Hosp. Manag., vol.80, no. February, pp.123-125, 2019, doi: 10.1016/j. ijhm.2019.02.004.

[9] A. F. Thaha, "Dampak Covid - 19 Terhadap UMKM di Indonesia," J. Brand, vol.2, no.1, pp.147-153, 2020.

[10] James L. Bess and J. R. Dee, "UNDERSTANDING COLLEGE AND UNIVERSITY ORGANIZATION Volume II, " Starling Virginia: Stylus Publishing, LLC, 2008, p.505.

[11] M. Reza, K. Pour, S. Abadi, A. Barzegaran, Z. Branch, and Z. Branch, "The Prioritization of Challenges in Smart Schools According to their Effectiveness from the Perspective of Teachers, " vol.5, no.3, pp.85-88, 2017.

[12] A. Hauser, F. Eggers, and S. Güldenberg, "Strategic decision - making in SMEs: effectuation, causation, and the absence of strategy, "Small Bus. Econ., vol.54, no.3, pp.775-790, 2020, doi: 10.1007/s11187 - 019 $00152-\mathrm{x}$.

[13] S. C. Eze, S. Olatunji, V. C. Chinedu - Eze, and A. O. Bello, 'Key success factors influencing SME managers' information behaviour on emerging ICT (EICT) adoption decision - making in UK SMEs, " Bottom Line, vol.31, no.3-4, pp.250-275, 2018, doi: 10.1108/BL - 02 - 2018 - 0008.

[14] O. Negulescu and E. Doval, "The Quality of Decision Making Process Related to Organizations' Effectiveness, " Procedia Econ. Financ., vol.15, no.14, pp.858-863, 2014, doi: 10.1016/s2212 - 5671 (14) $00548-6$.

[15] OECD, “The SME Financing Gap, " 2006. [Online]. Available: https: //www.oecd - ilibrary. org/finance and - investment/the - sme - financing - gap - vol ii_9789264029453 - en.

[16]L. Sumathy and C. Madhavi, "Influence of Emotional Intelligence on Decision Making by Leaders, " Am. Int. J. Soc. Sci., vol.4, no.1, pp.134-140, 2015.

[17] A. S. Moghadam and A. Ardakanian, "The Effect of Education and Educational Sciences on the Creativity and Social Adjustment of Students in District 4 of Tehran," 2019.

[18]P. A. Duignan and R. J. S. Macpherson, Educative leadership: A practical theory for new administrators and managers. The Falmer Press, 2004.

[19] B. George and S. Desmidt, "Strategic - Decision Quality in Public Organizations: An Information Processing Perspective, "Adm. Soc., vol.50, no.1, pp.131-156, 2018, doi: 10.1177/0095399716647153.

[20] D. J. Jang and H. J. Shim, "Development of a regulatory framework for risk - informed decision making, " Nucl. Eng. Technol., vol.52, no.1, pp.69-77, 2020, doi: 10.1016/j. net.2019.06.029.

[21] M. Ghasemaghaei, "Does data analytics use improve firm decision making quality? The role of knowledge sharing and data analytics competency, ” Decis. Support Syst., vol.120, pp.14-24, 2019, doi: 10.1016/j. dss.2019.03.004.

[22]B. F. Anderson, The Three Secrets of Wise Decision Making Three Secrets of Wise Decision Making Single Reef Press. Single Reef Press, 2002.

[23] Joan V. Gallos, Organization Development, vol.7, no.2. Jossey - Bass, 2006.

[24] K. B. Everard, G. Morris, and I. Wilson, Effective school management. 2004.

[25] A. Koerber and L. McMichael, "Qualitative sampling methods: A primer for technical communicators, " $J$. Bus. Tech. Commun., vol.22, no.4, pp.454-473, 2008, doi: $10.1177 / 1050651908320362$.

\section{Author Profile}

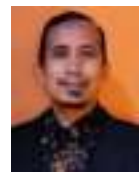

Budiono is Post Graduate Student of management at University of Technology Yogyakarta Indonesia. 
Sujoko is Post Graduate Lecturer of management at University of Technology Yogyakarta Indonesia.

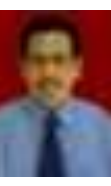

Sugiyono is professor of engineering education management at State University of Yogyakarta and University of Technology Yogyakarta Indonesia. 